Journal of Humanities, Social and Management Sciences (JHSMS)

eISSN: 2788-4791 (online)

https://doi.org/10.47264/idea.jhsms/2.1.11

Vol. 2, No. 1 (January-June 2021), 121-132

https://www.ideapublishers.org/index.php/jhsms

Research Article

\title{
War, refugees and regional implications: The impact of Afghan refugees on local society of Khyber Pakhtunkhwa, Pakistan
}

\author{
Asghar Khan*1 | Irfan Khan² | Noor Ullah Khan ${ }^{3}$ \\ 1. Department of Regional Studies, University of Peshawar, Peshawar, Pakistan. \\ 2. Department of Political Science, University of Buner, Sowari, Pakistan. \\ 3. Higher Education Department (HED), Khyber Pakhtunkhwa, Pakistan. \\ *Corresponding Author Email: mian_786pk@yahoo.com
}

Published: September 15, 2021

\begin{abstract}
Pakistan provided asylum to approximately 4.2 million during and after Cold War refugees. They were settled in 386 refugee camps mostly in rural as well as in urban areas of the country. But the most populous province that had large number of Afghan refugees was Khyber Pakhtunkhwa (KP) (that time N.W.F.P), which has long border (Durand line), and also has cultural, religious, and linguistics ties with Afghanistan. This large number of refugees generated grave consequences for Pakistan, especially for Khyber Pakhtunkhwa. They have affected the socio-economic and political life of the province. The main objective of this paper was to find out the socio-economic impact of Afghan Refugees living for more than three decades in the host society of KP. An empirical and analytical methodological approach was adopted for this study. To findings reveals that Afghan Refugees have not only affected the social set-up but also the economy of the local host society by introducing various type of social evils like begging, drugs culture, Kalashnikov culture (AK-47), Galemjum culture (prostitution) and corruption. Also, these refugees and their animals have impacted the ecological balance causing desertification and consequent soil erosion. The refugees have also promoted drug trafficking, illegal trade of arms, smuggling, sectarianism and other endless Law and Order problems.
\end{abstract}

Keywords: Saur Revolution, Afghan war, Afghan refugees, Soviet Union, socio-economic impacts, drugs, crimes, trade and commerce, prices and wages.

How to Cite: Khan, A., Khan, I., \& Khan, N. U. (2021). War, refugees and regional implications: The impact of Afghan refugees on local society of Khyber Pakhtunkhwa, Pakistan. Journal of Humanities, Social and Management Sciences (JHSMS), 2(1), 121-132. https://doi.org/10.47264/idea.jhsms/2.1.11

Publisher's Note: IDEA PUBLISHERS (IDEA Journals Group) stands neutral with regard to jurisdictional claims in the published maps and institutional affiliations.

Copyright: ( 2021 The Author(s), published by IDEA PUBLISHERS (IDEA Journals Group)

Licensing: This is an Open Access article published under the Creative Commons AttributionNonCommercial 4.0 International License (http://creativecommons.org/licenses/by-nc/4.0/) 


\section{Introduction}

The 1979 USSR invasion of Afghanistan has large scale implications on regional states of South Asia especially in the context of migration and refugees. The migration of Afghan refugees into Pakistan started in the wake of Saur (Red) Revolution in 1978, as a result of reforms introduced by the communist regime in Kabul, Afghanistan. A large majority of the uprooted Afghans took refuge in Pakistan, which proved a safe haven for them. The Pakistani state and society greeted the Afghan refugees with open arms because the people of the two countries are deeply tied in their historical, religious and cultural bonds. However, the large influx of refugees to Pakistan took place soon after the invasion of Soviet Union in 1979. The total Afghan refugees' population in Pakistan at the peak time in 1990 stood at 3.7 million. Today Pakistan is still home to over 2 million Afghan refugees including over 1.9 million staying in the N.W.F.P alone. Of them over 1.3 million are living in 48 regular camps while over 0.6 million are living in the urban and sub urban centres of the province outside the designated camps. Not depending entirely on the international aid, these Afghan refugees started earning their livelihood through labour. Profession wise Afghan refugees can be divided into following groups. These were labour class (60\%), business/trade (20\%), skilled class $(05 \%)$ and others $(15 \%)$. The pressure on the already meagre sources of Pakistan mounted further by the fresh influx of Afghan refugees who were forced to flee their country in large number due to the combined effect of continued draught condition, economic instability, internal civil war and military strikes by the US led alliance forces as part of the crackdown against international terrorism, has given a new dimension to the Afghan crises.

The continued presence of around 3.5 million Afghan refugees for more than quarter of century coupled with a gradual withdrawal by the UN agencies and their international community at large in September 1995 had a negative fallout for this province. Hosting this large number of refugees has not only affected the local economy but also created grave social consequences. In Pakistan about $3.5 \mathrm{~m}$ Population of Afghan refugees are living crowdedly in camps inside the N.W.F.P and Balochistan. This is a 'human time bomb' ticking away which has been placed inside Pakistan's sensitive Frontier regions through the courtesy of the Soviets (Effendi 1991, pp. 23-24). This large number and long-time presence of Afghan refugees has added to demographic overload of the population in the border region. The situation is affecting the economy and political stability of N.W.F.P and Balochistan provinces of Pakistan (Effendi 1991, pp. 23-24). The tribal areas of N.W.F.P are finding themselves gradually being sucked into Afghan politics. The activities of Malik Nadir Khan Afridi and his recent trans-frontiers Jirga (social gathering for resolving disputes) is a case in point. There are Pakhtuns on both sides of the Durand Line and with this decade long, conflict in Afghanistan and the intermingling of the trans-frontier populations, refugees Pakhtuns with their local kinsmen, could produce a new ferment of ideas and concepts which could be the source of the fresh international tensions and political aspirations (Effendi, 1991, p. 27).

For Pakistan, the 10-year war and the internal instability in Afghanistan for more than 25 years have painful consequences. Muslim resistance fighters, the mujahedeen's, set up supply bases inside Pakistan. Inevitably, Afghan refugees fled to Pakistan and the country suffered hundreds of air and ground attacks by the Soviet-Afghan forces on their border areas, as well as almost daily terrorist bombings against civilian targets. Approximately $4.2 \mathrm{~m}$ refugees, almost one quarter of the entire Afghan population came to Pakistan (Commissioner Afghan refugees 1980). Most of the refugees were settled down in rural areas of N.W.F.P and Balochistan in 
War, refugees and regional implications: The impact of Afghan refugees on local society of ...

386 camps because the cultural, religious and linguistic ties with the people of these both provinces (The Daily Dawn 1988). These Afghan refugees generated grave consequences for Pakistan in several areas.

\section{Objectives and methodological approach}

The main objectives of this research were to find out the socio-economic impact of Afghan refugees on the local host population of Khyber Pakhtunkhwa. For this paper both quantitative and qualitative primary data was collected. Quantitative data was collected through a structured survey questionnaire, while qualitative data was gathered through in-depth interviews from stakeholders. Primary data was collected from local host population, Afghan Refugees, businessmen, scholars and other experts. Data was analysed by using descriptive and inferential statistics in the form of frequencies and percentages. The qualitative data was analysed and presented in the form of views of the respondents. The population of the study was the city of Peshawar, however a sample of 100 respondents each were selected from two different areas on the basis of area that is near/adjacent to refugee's camp and the second sampled areas which is far from Afghan refugee's camps. Besides, from Peshawar city (urban area), a sample of 100 respondents were selected from the most important, busiest, and populated areas of the city through simple random selection criteria. The sampled areas include: Qissa Khawani (famous Bazaar and trading centre of Peshawar city), Afghan colony, Peshawar Cantonment and University town.

\section{Literature review}

Afghan refugees brought with them more than 2.5 million head of livestock (i.e. herds of sheep, goats, camels, cattle and yaks), which had a detrimental effect on the environment because of grazing on the scarce pasture land and fragile soil. The United Nations High Commissioner for Refugees estimates that the Afghan brought with them 45,000 camels and 25,000 donkeys for commercial purposes (Farr, 1990, p. 139). The refugees caused some resentment among the local people, particularly in relation to the control and use of grazing fields in N.W.F.P and Balochistan provinces. Indiscriminate and uncontrolled grazing ruined the sparse grazing grounds and extensively damaged the ecology of the green areas. The influx of Afghan refugees in N.W.F.P and Balochistan was a cause of serious deforestation in Pakistan's Chitral, Dir and Hazara division, as the refugee's sought firewood for cooking and heating (Samadani 1982, p. 26). Afghan refugees had a hand in using the free forest resources of the N.W.F.P-Balochistan, and virtually changed the landscape of these provinces. The result of the reckless cutting of forests was that land erosion took place upstream in the mountainous areas of Pakistan causing landslides and large-scale havoc and disruption of communication (Dawn, 1994).

Many skilled and unskilled Afghan refugees managed to secure employment, mainly in agriculture and the construction industry of Pakistan. They were powerful stimulus to the growth of markets in backward areas of the province and an abundant source of cheap labour in a labour-scarce environment. They secured a reasonable proportion of odd jobs in urban centres where they worked as a vendors, salesmen, waiters, shoeblacks, and construction workers, and so on (Boesen, 1990). In addition, many wealthier Afghan refugees invested capital in different types of commercial pursuits including real estate, transport and commercial properties. The purchase of immoveable property and inexpensive small retail shops caused a boom in real estate business, especially in the N.W.F.P, Balochistan, the urban centres of 
Punjab and Sindh, and along major highways. Wealthier class of Afghan refugees' generated tension with the local business class of because rents were pushed beyond the latter's reach. Refugees are also involved in the transport business of the N.W.F.P and Balochistan. It was estimated that more than 6000 Afghan vehicles were on 'temporary registration licences' and many without registration were plying the roads (Boesen, 1990, p. 166). In the N.W.F.P alone, there are over 893 heavy trucks, 55 large buses, 173 minibuses, 152 tractors, 411 cars, cabs, jeeps and pick-ups, and 21 motorcycles or rickshaws; a total of 1705 vehicles registered to refugees (Farr, 1990, p. 139) (and there were at least as many more vehicles unregistered). It was estimated that 60,000 Afghan families were supported by the motorised transport business in N.W.F.P and in the rest of Pakistan (Weinbaum 1993, p. 135). Again, resentment was created as the local indigenous population perceived themselves at an economic disadvantage.

The Afghan refugees also brought boom in illegal cross-border trade by Afghan vehicles. Shortage of wheat and rice in the Pakistani markets are blamed on the smuggling of these commodities to higher priced markets in Afghanistan, as well as India (Ahmad, 1993). There is hardly any major city in the country that does not have a market for selling smuggled foreign goods, ranging from crockery to household appliances, from clothes to petroleum products. Peshawar Bara Market is full of smuggled items such as air conditioners, refrigerators, televisions sets and all other types of electrical good (The News, 1994). Smuggling has hurt the Govt. of Pakistan finances hard in the form of lost revenues (estimated in the late 1990's to be around Rs. 4.7 billion annually) that it would have earned in custom duties and other levies had those goods come in through formal channels (The Economist, 1987). In late-1980s, the Afghan war led to Pakistan producing around 70\% of world's high-grade heroin (Beatty \& Gwynne, 1993, p. 954). Overseen by an estimated 40 drug cartels (Haq 1996, p. 521). This was developed and the problem started when CIA encouraged the mujahideen groups in Poppy cultivation (opium production to obtain money for arms against Soviet Union (Kartha, 1990). This business also created a powerful arms and drugs mafia in Pakistan, causing the expansion of the heroin and arms trade throughout the country. By the 1988, there were an estimated 100200 heroin refineries in the N.W.F.P province alone (Levitsky, 1989). By 1987-88, the drug trade was earning at least $\$ 4$ billion a year - more than foreign exchange than all Pakistan legal exports combined (Haq, 1996). In 1980s, drug addiction was relatively unknown to Pakistani and the poppy, was never cultivated on a high scale in the country but, between 1982 and 1987, the number of drug addicts increased from 124,000 to 450,000, including 5000 heroin addicts. Today, there are about 3.6 million drug addicts in Pakistan (Haq, 1996).

Kalashinkov (AK-47) culture flourished when US sent huge supplies of AK-47 Kalashinkov rifles through Pakistan to arm the Afghan mujahideen. Afghan war provided enormous opportunities for business in illegal arms in the N.W.F.P and the culture of Kalashinkov took firm roots in Pakistan. This has caused lot of aerial firings in the local society of Pakistan during ceremonies, which results in large number of casualties in daily life. In mid-1985, the Soviet Union and Kabul both launched psychological warfare against Pakistan to morally destabilise the society. For this purpose, the KGB and KHAD send hundreds of beautiful young girls of Afghan, Central Asian and Russian origin to corrupt Pakistani society. This flood first entered the N.W.F.P and later extended to the major urban centres of the country (Herald, 1992, pp. 23-28). So, with this a "Galemjum (Prostitute) Culture" emerged in Pakistani society, attracting professionals, the local commercial class, and frustrated youth in many urban centres. The existing hospitals and doctors' facilities were not sufficient to cater to the large-scale influx of Afghan refugees. The continued presence of these refugees further multiplied the miseries of 
War, refugees and regional implications: The impact of Afghan refugees on local society of ...

the local population. The hospitals became overcrowded. The poor and unhygienic living conditions in the camps resulted into various diseases like T.B, Hepatitis, and Lashminia etc (The Daily Mashriq, 1992). With the influx of Afghans, the children of the Afghan religious clerics got admission in religious seminaries. These Afghans students diverted attention of the locals from the prescribed syllabus/ course towards Afghanistan Jihad, smuggling, drugs and gun culture. They have also overcrowded educational institutes and have created problems for local children. They have created shortage of rented houses, other social problems and evils like begging, prostitution, interest practices, load shedding and shortage of water and sanitation problems (Daily Mashriq, 2000).

The Pashto and Persian music groups and bands of Afghan refugees have placed their old styled Pakistani competitors who mainly comprised of the retired military and police officials. The Afghan's tremendous success can be attributed to their use of innovative music. However, this trend enhanced obscenity especially during marriages and other happy occasions. Today sectarianism is the biggest and gravest threat to Pakistan's domestic security and integrity. During Taliban regime in Afghanistan, the bordering tribal Orakzai Agency first witnessed Taliban like movement (The Frontier Post, 1999). Its Impact also trickled down to the adjoining areas. This movement dominated by Sunnis of Orakzai Agency widened the gap between Sunnis and Shias (two different sects in Muslims), which finally resulted into the bloody sectarian clashes between the two sects. An example was the bloody clashes of Hangu district in March 1998, in which many innocents, precious lives were lost (Hussain, 1992, pp. 28-32). Influx of refugees caused lot of economic problems in local society. Due to the generous accommodative policy of Government of Pakistan, the Afghan refugees were not stopped from entering into the local labour market. The Afghan unskilled labour to a large extent squeezed out the local workers from the labour market as they could not compete with the Afghans who for the sake of their survival would accept the lowest amount of wages (Yousafzai, 1991). The Sarhad Chamber of Commerce and Industry reports that Afghan refugees have dominated the local trade by ousting the local businessmen from various traders including hotels, handicrafts, carpets, currency exchange, gold and embroidery. Have occupied transport industry, trucking and local transport services. The tourism industry in N.W.F.P suffered a severe setback, as tourist traffic from the west would not reach this part of the world via Kabul due to the distributed conditions in Afghanistan.

Great environmental damages have been caused by the continued presence of Afghan refugees in this province. The refugee's population in the hilly areas of tribal belt, Malakand, Hazara and Kohat division devastated forests and greenery (Hussain, 1982). Population congestion in the urban centres with disproportionate increase in the vehicular traffic on the adequate urban routes has been the main cause of population in the cities. According to the provincial police department in almost every major crime committed in the province, some Afghan refugees are invariably involved. This reflects the damaging effect of the continued presence of millions of Afghan refugees on the crime situation and the state of law and order in the province of N.W.F.P. Different criminal gangs and outlaws have created terror and fear among the local people. Many gang leaders and other influential hire services of Afghans at cheap rates for committing various heinous crimes or settling scores against their enemies. Some of the Afghan refugees in Pakistan have been able to obtain an N.I.C and passports and even enlisted themselves in voter list by impersonating themselves as Pakistanis with the collaboration of local leaders. These Afghans then commit various crimes abroad thus bringing bad name to Pakistan. The Afghan during their stay for more than a quarter of century have not only 
depleted the green forests but also actively involved in the smuggling of the valuable species of trees to different parts of the country and Afghanistan. The outlaws both locals and Afghans use Afghan refugee's camps as their shelter places. The criminal refugees commit crimes of various natures outside and seek protection in these camps from the law enforcing agencies.

In the early years of the mass influx of Afghan refugees, the international community particularly the UNHCR, WFP and other relevant UN agencies responded to the situation in a very positive and enthusiastic manner. The government of Pakistan played the role of a coordinator for settlement, relief, assistance, and rehabilitation of the Afghan refugees in Pakistan. The WFP provided generous food assistance for the Afghan refugees in Pakistan till 1989 (The New York Times, 1987). But after the inking of 'Geneva Accord', the WFP started pulling out of the scene gradually. Initially WFP started decreasing the scale of their general feeding program followed by drastic reduction in the items from the food basket for Afghan refugees. They totally discontinued the general feeding programme for Afghan refugees since 30th September 1995 (Rizvi, 1984). As per assessment carried out in 1991-92 by the Government of Pakistan in cooperation with UNDP in the areas of environmental degradation and damages caused to the infrastructure in Pakistan, the total loss works out to US \$ 208.00 million (Rupees 6240 million) in N.W.F.P and US \$ 760.884 million in Balochistan province. According to another survey conducted by the Government of Pakistan in 2000-2001, Pakistan has suffered a total loss of Rs. 8219.286 million due to Afghan Refugees. The details of the losses according to the provinces are: NWFP 5669.876 million, Baluchistan, 1828.250 million, and Punjab 8219.286 million.

Besides the above estimates, the Government of Pakistan from its own resources is spending lot of money on refugees (Govt. of Pakistan Survey 2000-2001). And has spent 'Rs. 12894.617 million on the establishment of Afghan Refugees Organizations since 1983 to 2003.' However, the total expenditure since October 2001 to February 2003 comes to Rs. 12929.447 million.

Table-2: Rehabilitation of N.W.F.P Post-Afghan solution

\begin{tabular}{|c|l|c|c|}
\hline \multirow{2}{*}{ S.No. } & \multicolumn{1}{|c|}{ Sector } & \multicolumn{2}{|c|}{ Sector wise estimated cost in millions } \\
\cline { 3 - 4 } & & (In PKR) & (In US Dollars) \\
\hline 1 & Forestry & 23.0 & 53.2 \\
\hline 2 & Pasture & 44.5 & 0.8 \\
\hline 3 & Livestock & 652.0 & 1.5 \\
\hline 4 & Drinking \& Sanitation & 450.0 & 21.8 \\
\hline 5 & Irrigation & 165.0 & 15.0 \\
\hline 6 & Health Services & 299.8 & 6.6 \\
\hline 7 & Education & 20.0 & 10.0 \\
\hline 8 & Manpower \& Training & 1203.0 & 0.7 \\
\hline 9 & Communication & 355.5 & 40.1 \\
\hline 10 & Transport & 480.0 & 11.9 \\
\hline 11 & Urban Development & 5288.8 & 16.0 \\
\hline \multicolumn{2}{|l|}{ Grand Total } & 208 million \\
\hline \multicolumn{2}{|c|}{ Cost assessed by UNDP } \\
\hline
\end{tabular}

Source: UNDP Pakistan country report (1992-94) 
War, refugees and regional implications: The impact of Afghan refugees on local society of ...

Table-3: Total expenditure of government of Pakistan (1979 - 1999)

\begin{tabular}{|l|l|c|}
\hline S.No. & Sector & Expenditures (In PKR Millions) \\
\hline 1 & Inland Handling of Relief goods & $6,538.942$ \\
\hline 2 & Maintenance allowance paid to refugee & $1,437.429$ \\
\hline 3 & Compensation paid to land owners of refugee camps. & 41,435 \\
\hline 4 & Payment of victims of aerial bombing & 29.439 \\
\hline 5 & Administrative expenditure of A.R Org: & 363.451 \\
\hline 6 & $\begin{array}{l}\text { Cost of 710,000 M.T of Wheat to cover the shortfall } \\
\text { in donations (1982-92) }\end{array}$ & $1,897.127$ \\
\hline \multicolumn{2}{|l|}{ Total } \\
The Total estimated Cost from 1999-2004 for the above & $10,307.823$ \\
\hline
\end{tabular}

Sources: Government of Pakistan, survey 2000 - 2001 by Commissionerate of Afghan refugees, Peshawar.

\section{Results and findings}

The withdrawal of World Food Program (WFP) and the reduction in relief assistance by the UNHCR caused set back to the overall relief work for Afghan refugees with serious repercussions on the socio-economic sectors of the country. The refugees could not sustain themselves without food assistance and had to look for employment opportunities outside their camps. Because there was no restrictions from Govt. of Pakistan on their movement or involving in any activity of day to day life like local people. This led to the movement of majority of the refugees to other centres of economic activities in search of livelihood. Afghan refugees being the victims of USSR strategic designs and also the pray of the cold war are long living a life of disaster in Pakistan for about quarter of century. These barefooted, homeless, vulnerable refugees brought with them many problems that worsened the existing weak social and economic and political set-up of the poor third world country. Pakistan. Here in this study the researcher main point of concentration is, to find out the extent of involvement of the refugees in local trade and commerce and business activities and to dig out that to what extent these long living refugees impacted socio-economic fabric of the local society. The impact is a broad subject of study, so the researcher only selected the most severe sectors the local society affected are given below in detail.

\subsection{Economic impacts}

The economic impacts on local society included the effect of Afghan Refugees presence on trade and commerce, employment and wages and on prices and rents

\subsubsection{Trade and commerce}

One peculiarity of N.W.F.P is that compared to other provinces especially Punjab and Sind it does not have an adequate industrial base. Agriculture sector in the other province is at a certain level of equilibrium as far as is concerned. It does not have the capacity to absorb or release large number of labours except for those who are added to the rural labour as a gradual increase in population or move out to urban jobs as part of the structural transformations, which the economy as a whole is registering. The availability of urban jobs is again subject to industrialization, which is taking place at a very slow speed in N.W.F.P. Traditionally N.W.F.P have had very lucrative trade relations with Afghanistan. The economy of Peshawar depends 
significantly on trade with Afghanistan. The war in Afghanistan, however, did not stop the trade with Pakistan. In 1984 daily "Muslim" reported that trade between Pakistan and Afghanistan was steadily increasing and registered an increase of 31 percent in that year (during these year in Afghanistan, the War was at the peak). The traditional imports, mostly fruits, were never disrupted during the war. In addition, the existence of tribal area in N.W.F.P has added to its business though most of this is in the informal markets. Over some years now, and especially during the presence of refuges, an amount parallel economy has emerged alongside the formal economy. The earnings in the tribal areas have resulted in huge investments in the major cities of N.W.F.P particularly Peshawar. Now data or official record is available in this regard but the extent and the traits of such an economy is ostensibly visible. The investment in Peshawar has not only been in the real estate and formal trade and business but a huge investment is visible in contraband items on the fringes of the tribal boundary and now inside Peshawar town. The mushrooming of markets dealing in smuggled goods all over the country is not a recent or post 1979 phenomena but existed for more than 25 years. This tendency of markets dealing in smuggled goods has increased many folds during the period under study i.e., 1979 to 2004 . Previously the goods were mainly originated from Western Europe and Japan.

To this new addition is made of Russian goods and also Chinese goods in majority mainly electronics and cloth. Peshawar district has a flourishing trade in contraband items. The Govt.'s policy on this type of trade has been somewhat unexplained. When these markets existed in the tribal belt, the entry of goods in to settled areas was checked. But now that these markets exist in the settled area the goods are checked when move from one city to another i.e., the main check post exist on the border of N.W.F.P and Punjab at the Khairabad bridge (Attock bridge). Whatever, the Govt. policy, the fact is that these markets have flourished in the settled areas and Afghan traders own a large percentage of these shops. Not only that Afghans are engaged in smuggled goods business but whatever and whenever a business opportunity has arisen the refugees have taken them. There have been two reasons: Firstly, the increased population of N.W.F.P due to the refugee's influx needed additional services, to meet additional demand. To this both the local population and the refugees have responded by investment wherever, feasible. Secondly, the Afghan refugees have brought with them resources that they have invested. Even if the rate of return was relatively lower here in N.W.F.P than the going rate. The concentration of investment in N.W.F.P was mainly due to their limitation to freely move out to other parts of Pakistan. Thus N.W.F.P and Balochistan remained the main centres of investment. (This does not mean that the Afghans have not invested in business in other parts of Pakistan, Islamabad and Karachi being the other main towns of refugee's investments). This increased the numbers of shops and trade in N.W.F.P. It was observed while talking to both local and refugee's population that large number of refugees are doing business in small margins and charge competitive prices mainly to establish their business. Many local traders observed that their (refuges) incomes are supplemented by the aid they get through outside agencies and the govt. of Pakistan. Also, since they do not have many social obligations like the local traders and don't pay the taxes they can afford to work on smaller margins and still make profits. Thus, the local traders are the main sufferers of this situation. They are facing tough competition from the refugees. In many markets in Peshawar, local traders have switched their trades or moved out. This is especially true of vendors where the researcher investigation revealed that the refugees have taken over a big business from the local population, obviously the general consumer is benefited because he enters, a relatively buyers' market. 
War, refugees and regional implications: The impact of Afghan refugees on local society of ...

The main investigation of this study was therefore done in the trade and commerce section of the economy of N.W.F.P. The four sample areas were chosen in Peshawar metropolis to compare with locals and workout the extent to which Afghan refugees were involved in the economy of N.W.F.P. In these four sample localities the selected trading centres were chosen for this analysis comprising area from one side (start of the city) of Peshawar to the other end of the city, i.e., from General bus stand to Hayatabad. In all the main trading centres selected, universal count was made of the entire business and retail points. The selected centres included: a). Qissa Khawani, b). Afghan colony, c). Peshawar cantonment, and d). University town. Trade and commerce were studied from two angles. Here it was assumed that due to the influx of refugees in such large numbers of new markets will emerge and new construction activities will take place. In addition to availing the existing capacity the refugees would create additional demand for markets. Therefore, two types of count were made in this regard.

One in the old established markets and the second one in the newly constructed markets and shopping centres, which were constructed after 1979. the important factor in probing into the trade and commerce was that huge investments are made in this business. The count in the prime areas of the city would reveal the extent of investments by refugees. The shops in the prime area are bought at high advance payments as good will money by these Afghan refugees. Investigation was made to realize data on the extent of investment made by the refugees. There is no doubt the investment is excessive. The data generated did not convince the researcher to be the right figures. Quite obviously no businessman would reveal the extent of investment made to stranger enumerator seeking such data. The fears are many for such traders to reveal the extent of their business. In the absence of authentic data, it was decided not to probe further into this matter. Neither the rent nor the size of investment was revealed by both the Afghan and local respondents. The local respondents however, revealed the ownership but not the rents or investment. However, the count in the prime areas of Peshawar reveals the investment of refugees in numbers and the kinds of business. Keeping in view the frequency of numbers, in all 31 trades and professions were identified, the ones, which were significant, were counted and the insignificant were omitted.

\section{A. Analysis of trade centres}

\section{A.1. Qisa Khawani}

Qisa khawani is one of the most important business centres of Peshawar. It is not only important from business point of view, but it is also a centre of attraction for all tourists and visitors visiting Peshawar because of historical importance and familiarity and is the oldest bazaar of Peshawar. The new entrants into this business centre should find it very expensive and difficult to establish business here. A shop may cost between 500,000 to 1 or 2 million rupees as goodwill money. It was founded that $91 \%$ of carpets and antiques $33 \%$ of leather and shoes business, $29 \%$ of hotel and restaurants and $15 \%$ of cloth business was taken over by the refugees. After 1980 (the year of settlement of refugees in Peshawar) no new shopping centres or markets were constructed in Qisa Khawani because the bazaar is old and there is not a single inch space to construct a new building. The influx of Afghan refugees and their investment in business took over established shops from the local population. In other words, the local population made away for the refugees. Obviously paying high goodwill prices. In all 62 shops were owned by the refugees here compared to 237 owned by the locals. The refugees, therefore, owned about $26 \%$ of shops. It is difficult to assess the amount of investment by the refugees 
but if only goodwill is worked out at the rate of Rs. 300,000 per shop an investment of Rs. 19.5 million is an approximate value of investment in Qisa khawani by the refugees as goodwill money only. The value of the contents of the shops can be any body's guess.

Vending is very popular in all the parts of the city. The refugees especially the poor ones found this very handy and easy establish. The Municipal Corporation administratively controls the vending business, but the control is largely ineffective. The field staffs of the Corporation on small gratification allow vendors to operate even if they are operating without license. The Afghan refugees have, therefore, taken a sizeable market in vending. In Qissa khawani it was found that refugees have almost equal or more share in vending compared to the local vendors. In cloths, carpets and crockery business, they have a larger share and very close in leather and shoes and general merchants. Only in fruits and vegetables, 38\% restaurants, $28 \%$ and electric goods etc $38 \%$ they follow the local vendors. Normally vendors hire their carts on daily basis payments to the owner of the carts in which they sell their goods. The investment of each vendor may be in the range of Rs. 1000 up to 5000 (sweets and cigarettes) to 10,000 rupees for carpet sellers who carry carpets on their shoulders or carts selling these in the streets.

\section{A.2. Afghan colony}

Afghan colony lies on the peripheries of main city centre but has become a part of the main city centre even before the refugees arrived. The name of the colony has nothing to do with the Afghan refugees and it got its name much before the arrival of Afghan refugees. The area was chosen as this was mainly a residential area and the only shops, which existed here, were catering for local residents selling items of daily consumption. After the arrival of Afghan refugees Afghan colony became one of the big refugee markets. This market mostly sold used items of army uniforms, shoes, tents, bags etc, which sent by different donor agencies for use in war (Soviet-Afghan war (1979-1986).

The local population found cheap camping and outdoor outfits here. The market flourished in mostly banned items, as the local Commissionerate office at Peshawar would periodically raid these shops stopping them to sell army used items. Perhaps it was the bad name it brought to the Govt. and the Mujahideen, which was the main concern of the local administration. In the last couple of years, the local administration has not interfered. To find out what happened to the local shopkeepers after the market in these goods were established. A count was made and found that the entire market has been taken over the Afghan refugee's traders. Except for small share in cloth business i.e., $9 \%$ held by the local population, business where not a single Pakistani was found compared to just 2 shops of the locals the refugees had 105 shops. The Afghan colony is not very expensive area. A shop may cost between 50,000 to Rs. 100,000 as goodwill money. If an average of Rs.75, 000 is taken as goodwill money the investment by refugees comes to Rs. 7.8 million in this area. In vending the refugee occupied the entire market. There were 503 vendors here without a single local vendor.

\section{A.3. Peshawar Cantonment}

The involvement of refugees in trade and business in Peshawar cantonment was not substantial. Cloth 29\%, carpets and Antiques 50\%, handicrafts 31\% were the main trades of refugees in Cantonment. The cantonment area follows the same pattern as in other parts of Peshawar where the refugees have large share in cloth, carpets, antiques and handicrafts. 
War, refugees and regional implications: The impact of Afghan refugees on local society of ...

\section{A.4. University town}

University town is close to the biggest refugee concentration around Peshawar. It has two large tent villages Nasir Bagh and Kacha Gari. The university town is the suburb of Peshawar and relatively a new and modern residential area of Peshawar. It has a sizeable population of all foreign missions who arrived here in Pakistan in connection with the influx of refugees. The UNHCR sub-office is also located here. Almost all the head offices of foreign missions (NGO's and other relief and humanitarian aid agencies) and the Afghan resistance groups are located in university town. The involvement of refugees in business here was significant and as would be evident from counting, $56 \%$ of cloth, $83 \%$ of carpets, $53 \%$ of tailors, $46 \%$ of general merchants, $48 \%$ of hotel and restaurants, $31 \%$ of fruits and vegetables, 314 shops held by locals the refugees occupied 139 shops. The cost of goodwill in university area average about Rs. 100,00/-. This makes refugee investments to Rs. 14 million in this area. Regarding new shopping centres the refugees owned 10 shops against 32 held by the locals. The approximate investment comes to around Rs. 1 million. In vending business, the refugees almost dominated the local population with $52 \%$ in fruits and vegetables, $66 \%$ in leather and shoes, $100 \%$ in general merchants, blacksmiths, tailors, handicrafts, books and stationery and butchery was held by the refugees. Since the refugee's population was mostly concentrated around the university town so, the refugee's business also flourished in the nearby area. There were 288 refugee vendors against 139 locals here.

If we see the overall situation in Peshawar city and cantonment the picture that emerges is that $33 \%$ of entire cloth business is held by the refugees, $23 \%$ of the tailors are refugees, $71 \%$ of carpets and antique business is held by refugees, $19 \%$ of hotels and restaurants, $14 \%$ of general merchants, $11 \%$ of leather and shoes, $32 \%$ in handicrafts, $18 \%$ of blacksmiths are refugees. This is the position as far as the shops (either owned or rented held by the Afghan refugees in Peshawar city and Cantonment areas. In all 1748 the locals against 326 by the refugees held the rest of the shops. This is regarding the number of shops in the old shopping centres in the sample area. In vending business in the entire Peshawar city and Cantonment refugees have a bigger share. In cloth they hold $62 \%$ share, $52 \%$ in crockery, $56 \%$ in general merchants, $56 \%$ again in carpets and antiques, $42 \%$ in leather and shoes, $34 \%$ of barbers, $53 \%$ carpenters, $28 \%$ of restaurants and $47 \%$ of fruits and vegetables are held by refugee traders.

\section{A.5. New markets}

The figures so far given were related to the old markets and shops. Counting was also done in the newly established shopping centres and markets, which were constructed after the influx of refugees in Peshawar. Here the story is different. In Peshawar city in all the newly constructed shopping centres the refugees have mainly occupied 3 business i.e., general merchants where their share has been found to be $80 \%$ of the entire city shops, carpets and antiques in which they had $100 \%$ business, cloth in which they held $41 \%$ of the share. In cantonment area in which the newly constructed markets refugees occupied $59 \%$ of all cloth business, $22 \%$ of crockery, $21 \%$ of general merchants and $18 \%$ electrical and musical centres.

\subsubsection{Employment and wages}

For many Afghan refugees Pakistan was not a new country. Traditionally, people have been moving into Pakistan particularly in N.W.F.P for seasonal jobs, trade and finding pastures 
during the winters. The Afghans have always found N.W.F.P a convenient place to move into. The Government of Pakistan practically had a very lenient policy for Afghans in this regard. Even before the Russians moved into Afghanistan many Afghans were living in Pakistan. After the April revolution and disturbances in Afghanistan N.W.F.P became a natural and convenient place for the disturbed section of the Afghan population to move in. it is quite obvious that those refugees who moved into Pakistan will not be sitting idle but will involve themselves in some economic activity. This become easier when there are no restrictions by the local administration on the refugees from the Government of Pakistan and the International Agencies was not enough to sustain themselves. The refugees, therefore, in addition to self-employment have taken up and entered into the labour market full-fledged.

Most of the refugees who are living in camps were the poor section of the population in Afghanistan. Afghanistan being a less developed, agricultural country, therefore the refugees were mostly unskilled agricultural workers. A number of refugees found work in the farm sector. Since the farm sector in Frontier did not have much absorption capacity and secondly these jobs were of seasonal nature majority of the refugees labour subsequently entered into urban jobs market, which consisted of mostly construction and other day-to-day casual work including service industry. This large number of refugees entering into the labour market increased the supply of labour. It was expected that the refugees would compete for jobs with the local population and lower the wage rate. According to the Government of Pakistan statistics, Peshawar had the lowest rate in the wage of unskilled labour category after the refugee's arrival.

Table-4: Wages for unskilled workers in different cities of Pakistan in 1984

\begin{tabular}{|l|c|c|}
\hline S.No. & City & Wages (PKR) in 1984 \\
\hline 1 & Gujranwala & 35 \\
\hline 2 & Hyderabad & 40 \\
\hline 3 & Islamabad & 33 \\
\hline 4 & Karachi & 35 \\
\hline 5 & Lahore & 37 \\
\hline 6 & Faisalabad & 28 \\
\hline 7 & Multan & 28 \\
\hline 8 & Quetta & 28 \\
\hline 9 & Peshawar & 25 \\
\hline 10 & Rawal Pindi & 34 \\
\hline 11 & Sialkot & 38 \\
\hline 12 & Sakkar & 30 \\
\hline
\end{tabular}

Quoting from the Directorate of Works N.W.F.P agricultural university has analysed that wage rate in Peshawar increased by rupees eight between 1975 and 1980 (during this period the Afghan refugees were not migrated to Pakistan). But between 1980 and 1985 (during this period Afghan refugees are migrated to Pakistan and were totally involved in day-to-day affair of the local society) the increase was only Rs. 5. The two phenomena of inflation and labour migration to Gulf has resulted in increased wage rate all over country. In Peshawar this increase has been arrested mainly due to refugee labour. The wage rate during 1972-86 is given in the following table: 
War, refugees and regional implications: The impact of Afghan refugees on local society of ...

Table -5: Year wise wages of unskilled workers (In PKR)

\begin{tabular}{|c|c|c|}
\hline S.No. & Year & Wages (PKR) \\
\hline 1 & 1972 & 5 \\
\hline 2 & 1976 & 20 \\
\hline 3 & 1980 & 25 \\
\hline 4 & 1984 & 25 \\
\hline 5 & 1986 & 30 \\
\hline 6 & 1990 & 36 \\
\hline 7 & 1995 & 45 \\
\hline 8 & 2000 & 60 \\
\hline 9 & 2994 & \\
\hline
\end{tabular}

The wages did not change between 1984 and 1986. Though Pakistan, like many other developing countries have a relatively high inflation rate. (Govt. sources admit a single digit rate but independent sources claim 10-12\% rate). The author talked to various agencies involved in construction business. The contractors who were the main source of information were of the opinion that refugee labour has kept the wage rate low in Peshawar. They no more face the harvest season labour shortage when all their labour would immediately move out to the villages for harvesting crops. Now the refugee's labour is abundantly available if the local move out to the countryside during time. This they say was a major problem in the construction industry before the arrival of the refugees. They, however, had this notion that where the problem in the unskilled category is no more there the Afghan skilled labour is not having the same quality as locals. Obviously, the main sufferer of this situation was the Pakistani unskilled labour. Therefore, surveys were conducted to investigate these phenomena. One was done in village Regi which is close to one of the main refugee concentrations, the second study was conducted in village Chughar Mati which is at a distance from the refugee camps and did not lie in the mainstream of their movements.

\section{A. First sample area}

The first Sample area was selected because it was close to the refugee camps and the city, and it was expected that the refugees would directly affect the people of Regi. A sample of 100 males at random was chosen. The selection was mainly based on the first available 100 persons rather than any other criteria. This sample of 100 respondents was mainly in the age group 20 to 50 i.e., $73 \%$ of the sample was in this age group. They were all married, majority illiterate (89\%). The mean family size was 7 persons per family. In this sample $43 \%$ were casual labours and $32 \%$ unskilled workers with permanent jobs i.e., they were cleaning sand used for construction and supply material to the constructor. The other were $3 \%$ farmers and rest village artisans i.e., butchers, barbers, blacksmiths, carpenters, tailors, drivers. $6 \%$ were self-employed in grocery shops. All of these were employed or found jobs, regularly before the arrival of the refugees. The first question to these people was whether their jobs were affected due to the Afghan refugees. All said that in one way or the other the refugees affected their jobs. $44 \%$ said that on the average one week in a month they can't find work due to the influx of refugees' workers, $29 \%$ said that half a month is without work and only 275 were on the job the whole month. Most of them i.e., $52 \%$ had this apprehension that in future they will be jobless if the refugees stay her for the next few years only $48 \%$ said that they will be able to compete in jobs 
with the refugees. The respondents also revealed that compared to the before refugee situation now they have to travel at least 10 to 15 miles to find jobs. Regarding the extent of earning by both the categories i.e., refugees and locals $39 \%$ of the respondents said that the refugees labour earn more than them while $52 \%$ said that they earn better and $9 \%$ were not sure. Regarding the efficiency and performance of the refugee labour $21 \%$ of the respondents said that the refugees are more efficient but $79 \%$ said that the local labour is more efficient and hardworking than the refugees' labour. The respondents were asked to explain in what way the living standards have been affected. They were given four items i.e., Food, Clothing, Transport and Education to explain whether they were better off or worse after the arrival of the refugees. The following table gives their responses.

Table-6: Living standard of the local respondents after the Afghan refugees' arrival

\begin{tabular}{|l|c|c|c|c|r|}
\hline \multirow{2}{*}{ Various Items } & \multicolumn{3}{|c|}{ Standard of: } & \multirow{2}{*}{ Total } \\
\cline { 2 - 5 } & Better & Worsened & Unchanged & Don't Know & 100 \\
\hline Food & & 100 & & & 100 \\
\hline Clothing & & 100 & & 1 & 100 \\
\hline Transport & 41 & 58 & & 28 & 100 \\
\hline Education & & 72 & & & \\
\hline
\end{tabular}

The explanation given for (1) was that food available is now expensive and since their earnings have come down, they cannot maintain the former eating habits. Regarding item (2) again it is the low earnings, which has resulted in lesser use of clothes. Regarding item 3, 41\% said that the transport frequency has increased but these are always full, and they have to wait long to get seats. Regarding item (4) $72 \%$ said that the schools are full of refugee children they get less chances of admitting their children or their children enjoys less facilities and low attention in schools due the influx of refugee children.

\section{B. Second sample area}

The second sample area was a village called Chagar Matti. It is a village with a population of 13165 people and having an area of 1795 acres. It is again purely an agricultural village. This village was selected, as it is not close to any refugee camp. It is located away from the mainstream of movement of the refugee population. The size and sample were 100 male members of the village. The basis of the selection was the same as in Regi. The majority i.e., $78 \%$ of the sample was the age group of 20 to 50 years of age, $92 \%$ were married the mean family size was 6 . The literacy rate was merely $14 \%$ and $86 \%$ of the respondents were illiterate. The occupation of the respondents was $60 \%$ casual labourers, $14 \%$ illiterate farmers, $6 \%$ masons, $4 \%$ self-employed shopkeepers, $6 \%$ barbers and mechanics. Here too the respondents were asked whether they were affected with influx of refugee or not. $78 \%$ of the respondents said that their jobs were affected and $22 \%$ said that refugees did not affect their job situation. In this village $50 \%$ of the respondents were working for 15 days a month compared to 30 days before the arrival of the refugees, $38 \%$ for 20 days a month, $3 \%$ for 25 days a month and only $9 \%$ were unaffected, employed for the entire month.

All the respondents whose job was not affected by the refugee labour were farmers, tailors, shopkeepers, barbers and mechanics. The rest, who came mostly under the casual work category were one way or the other way affected by the refugee labour. Those who were 
War, refugees and regional implications: The impact of Afghan refugees on local society of ...

affected by the refugee labour, $66 \%$ said that they were affected due to less job opportunity and lower wage rate. $10 \%$ were affected because their crops were destroyed by the refugees, and they steal their firewood. Only $22 \%$ of the respondents said that they were not materially affected the refugee population. The respondents were asked if they had lost jobs in the past due to competition with the refugees, $62 \%$ said that they often did lose their jobs in competition with the $r$ refugees and only $38 \%$ were of the view that they have not lost their jobs to the refugees in the past. Regarding the apprehension of local population for losing jobs in future $40 \%$ said that they fear losing jobs in future $40 \%$ said that they fear losing job to the refugees in the future. $50 \%$ said that they were not likely to lose jobs in future and $10 \%$ were not sure. Regarding the efficiency and job performance of the refugees compared the local population $18 \%$ of the respondents believed that refugees are more efficient and hardworking, 68\% believed that the local labours are better workers and $24 \%$ were not sure. The question of whether their standard of living become better or worse for the 4 selected items. The responses are given in the following table.

Table-7: Percentage of the standard of living of the responding after the Afghan refugee's arrival

\begin{tabular}{|l|c|c|c|c|}
\hline Standard of Living/Items & Food & Clothing & Transport & Education \\
\hline Better & - & - & 62 & - \\
\hline Worsened & 78 & 78 & 18 & 30 \\
\hline Unchanged & 22 & 22 & 20 & 26 \\
\hline Don't know & - & - & - & 44 \\
\hline Total & 100 & 100 & 100 & 100 \\
\hline
\end{tabular}

The reasons, for lower standards in food and clothing were the same given by respondents in first village i.e., Regi. The only category where they felt an improvement has taken place in transport where $62 \%$ of the respondents said that now transport is more frequently available and is of better quality than before. Regarding education, $30 \%$ were of the view that the seats available in the schools are filled up by the Afghan children, $26 \%$ said that there has been no difference and $44 \%$ said that they do not sent children to schools, so they don't know what effect the refugees have brought in this sector. Refugees are ready to work on lower wages because essential items like food are available free to them by the Govt. They also said that they have to accept lower wages to compete with them. $100 \%$ of the respondents were of the view that if they do not lower their wages, they will be unemployed. To the question whether the refugees' earnings are higher than yours, $100 \%$ said yes whereas their own earnings have come down. They were asked whether there conflicts due to job competition between refugees and local population, 94\% said yes. They were asked whether you were personally involved in any kind of conflict once or more in the past. The respondents revealed that had main profession of the village people was in the casual category with the refugees. A question was asked whether the local labour get jobs in the same localities or have to go elsewhere after the arrival of the refugees. All said they do not always get work in the same area, $66 \%$ respondents said they have to travel for 10 to 15 miles on the average more to find jobs than they used to find before the arrival of the Afghan refugees.

\subsubsection{Prices and rents}

The arrival of more than 3 million people in a short span of time to region has on very obvious consequence that that the general prices level of that region will change. It is logical to conclude that those items whose demand cannot be adjusted to supply will register an increase. Those 
items whose supply has increased without corresponding increase in demand will experience a decline. Since the Afghan refugee's concentration is in Peshawar district. This variation in prices would be more apparent here. Finding change in prices of essential foodstuff in Pakistan is somewhat easy. The government maintains a very strict vigilance on prices of essential items like wheat, sugar, and edible oil in particular. Other items like vegetables etc are also watched. Since food composes a large percentage of household budgets of majority of the population any increase in food prices is immediately dealt with. The communication systems and media are very prompt in reporting this phenomenon. It was therefore decided that these should be the major sources for information on price variation. ${ }^{1}$

The government sources are quite reliable as far as essential items like wheat sugar and edible oil is concerned because the Government has major intervention in the marketing of these commodities. As regard, other items like milk, vegetables and meat it is observed that though Government monitor their prices but take a lenient stand on these items. The Government continues to publish the prices of essential items periodically. Quoting from Government sources the researcher compares the prices deviation between the period 1975-80 (then non refugee's situation, when there were no refugees in Peshawar (Pakistan)) and 1980-85 (the refugees' situations, there was an influx of refugees in Peshawar (Pakistan)). Another comparison is made in the prices of essential commodities over the period 1975-85 between the major cities of Pakistan, which were not exposed to refugee's influx and Peshawar (which is the hub of refugees' population). The relevant data is reproduced in tables 7(a) and 7(b). The subsequent analysis is also given.

Table-7(a): Average retail prices in rupees of basic articles of consumption

\begin{tabular}{|c|c|c|c|c|c|c|c|c|c|c|c|c|}
\hline \multirow{2}{*}{ Year } & \multicolumn{4}{|c|}{ 1. Wheat Flour $/ \mathrm{kg}$} & \multicolumn{4}{|c|}{ 2. Beef, $(\mathrm{Cow}) / \mathrm{kg}$} & \multicolumn{4}{|c|}{ 3. Milk (Buffalo)/litre } \\
\hline & $\mathrm{Kc}$ & Lhr & R.P & Pwr & $\mathrm{Kc}$ & Lhr & R.P & Pwr & $\mathrm{Kc}$ & Lhr & R.P & Pwr \\
\hline $1974-75$ & 1.52 & 1.25 & 1.26 & 1.39 & 7.39 & 5.58 & 5.13 & 5.38 & 3.06 & 2.35 & 2.34 & 1.91 \\
\hline $1975-76$ & 1.55 & 1.13 & 1.29 & 1.31 & 8.07 & 6.10 & 5.32 & 6.15 & 3.70 & 3.44 & 2.79 & 2.31 \\
\hline $1976-77$ & 1.65 & 1.26 & 1.29 & 1.18 & 9.38 & 6.42 & 5.51 & 6.34 & 3.97 & 2.85 & 2.67 & 3.26 \\
\hline $1977-78$ & 1.75 & 1.39 & 1.37 & 1.42 & 8.00 & 6.43 & 5.77 & 6.42 & 3.74 & 2.89 & 2.96 & 4.04 \\
\hline $1978-79$ & 1.97 & 1.67 & 1.45 & 1.69 & 9.06 & 7.16 & 6.52 & 6.76 & 3.85 & 2.91 & 3.47 & 3.67 \\
\hline $\begin{array}{l}\text { Increase in } \\
\text { last } 5 \text { years. }\end{array}$ & 0.45 & 0.42 & 0.19 & 0.35 & 1.67 & 1.48 & 1.39 & 1.38 & 0.79 & 0.56 & 1.13 & 1.76 \\
\hline $\begin{array}{l}\text { (\%)Variation } \\
1974-79\end{array}$ & 29.6 & 33.6 & 15.00 & 26.1 & 22.5 & 28.3 & 29.0 & 25.6 & 25.8 & 23.8 & 48.2 & 92.1 \\
\hline $1979-80$ & 2.13 & 1.74 & 1.53 & 1.65 & 9.20 & 8.50 & 7.22 & 7.57 & 4.08 & 3.00 & 4.03 & 3.50 \\
\hline $1980-81$ & 2.25 & 1.82 & 1.46 & 1.64 & 12.75 & 9.67 & 8.17 & 9.05 & 4.66 & 3.12 & 4.68 & 3.64 \\
\hline $1981-82$ & 2.46 & 2.03 & 1.89 & 1.96 & 13.83 & 10.83 & 9.56 & 11.17 & 5.18 & 3.54 & 5.18 & 4.04 \\
\hline 1982-83 & 2.50 & 2.07 & 2.06 & 2.16 & 11.00 & 11.24 & 10.00 & 12.71 & 5.50 & 4.00 & 5.78 & 4.71 \\
\hline 1983-84 & 2.66 & 2.21 & 2.23 & 2.23 & 15.32 & 14.02 & 10.00 & 13.17 & 6.27 & 4.13 & 6.09 & 5.00 \\
\hline $\begin{array}{l}\text { Increase in } \\
\text { last } 5 \text { years }\end{array}$ & 0.53 & 0.47 & 0.77 & 0.58 & 6.12 & 5.52 & 2.78 & 5.60 & 2.19 & 1.13 & 2.06 & 1.50 \\
\hline $\begin{array}{l}\text { (\%)Variation } \\
1979-84\end{array}$ & 24.8 & 27.0 & 50.3 & 35.1 & 66.5 & 64.9 & 38.5 & 73.9 & 53.6 & 37.6 & 51.1 & 42.8 \\
\hline
\end{tabular}


War, refugees and regional implications: The impact of Afghan refugees on local society of ...

The table gives comparison of the prices of six consumable commodities prevalent between 1974 and 1984 in four major cities of the country including Peshawar. The data have been split into two parts. The first part deals with the net and percentage change in prices of the given commodities from 1979 and the other part deals with the period from 1979 to 1984 . The method has made possible the study of the trend in the price in change in various cities prior to the refugee factor and the trend obtaining in those cities after the refugees moved into Peshawar in large numbers ever since 1979. In the first part of the table, it is observed that apart from the prices of Kerosene oil, the prices of all other commodities have registered a considerable increase which is in no case is less than $15 \%$ (change in price of wheat flour in Rawalpindi) and in some cases as much as $100 \%$ (change in price of onion in Rawalpindi). At an average the prices of all the listed six commodities at Karachi rose by 36\% during 1974-79 period; at Lahore by $39 \%$ for five commodities (except Kerosene oil); and at_Peshawar by as much as $62 \%$ for five commodities (except Kerosene Oil, when it fell by \&\%). This analysis shows that Peshawar was most adversely hit by the inflationary trends during 1974 and 1979. Looking at the second part of the table and going by the same method, it is observed that price hike for all the six commodities on average basis during 1979-1984 for various cities were: Karachi (54\%), Lahore (50\%), Rawalpindi (53\%) and Peshawar (52\%) (Deducted from above Table).

Table-7(b): Average retail prices in rupees of basic articles of consumption

\begin{tabular}{|c|c|c|c|c|c|c|c|c|c|c|c|c|}
\hline \multirow[t]{2}{*}{ Year } & \multicolumn{4}{|c|}{ 4. Onion $/ \mathrm{kg}$} & \multicolumn{4}{|c|}{ 5. Firewood (kieker)/kg } & \multicolumn{4}{|c|}{ 6. Kerosene oil/paint } \\
\hline & $\mathrm{Kc}$ & Lhr & R.P & Pwr & K.c & Lhr & R.P & Pwr & $\mathrm{Kc}$ & Lhr & R.P & Pwr \\
\hline $1974-75$ & 0.93 & 1.08 & 1.05 & 1.07 & - & 13.56 & 13.23 & 12.86 & 0.49 & 0.68 & 0.67 & 0.68 \\
\hline $1975-76$ & 1.48 & 1.80 & 1.70 & 2.74 & 13.75 & 14.53 & 12.06 & 17.80 & 0.60 & 0.75 & 0.75 & 0.75 \\
\hline $1976-77$ & 1.99 & 2.31 & 2.28 & 2.20 & 16.05 & 15.72 & 15.28 & 20.37 & 0.63 & 0.77 & 0.73 & 0.73 \\
\hline $1977-78$ & 1.73 & 1.98 & 2.16 & 2.16 & 15.97 & 16.68 & 17.92 & 21.69 & 0.55 & 0.56 & 0.56 & 0.60 \\
\hline $1978-79$ & 1.75 & 1.99 & 2.10 & 2.05 & 16.16 & 16.82 & 18.61 & 22.46 & 0.65 & 0.67 & 0.62 & 0.63 \\
\hline $\begin{array}{l}\text { Increase in last } \\
5 \text { years. }\end{array}$ & 0.82 & 0.91 & 1.05 & 0.98 & 2.41 & 3.26 & 5.38 & 9.60 & 0.16 & 0.01 & 0.05 & 0.05 \\
\hline $\begin{array}{l}\text { (\%) Variation } \\
1974-79\end{array}$ & 88.1 & 84.2 & 100 & 91.5 & 17.5 & 24.0 & 40.6 & 74.6 & 32.6 & 1.4 & 7.4 & 7.3 \\
\hline $1979-80$ & 2.39 & 2.73 & 2.81 & 2.84 & 19.04 & 20.92 & 20.88 & 14.9 & 0.95 & 0.97 & 1.15 & 0.93 \\
\hline $1980-81$ & 1.86 & 2.00 & 2.12 & 2.08 & 25.58 & 28.25 & 14.17 & 37.10 & 1.00 & 1.46 & 1.72 & 1.46 \\
\hline $1981-82$ & 3.03 & 3.16 & 3.31 & 3.26 & 28.91 & 32.67 & 32.08 & 32.50 & 1.65 & 1.50 & 1.73 & 1.50 \\
\hline $1982-83$ & 2.13 & 2.24 & 2.40 & 2.42 & 29.07 & 32.59 & 32.72 & 33.98 & 1.65 & 1.51 & 1.74 & 1.50 \\
\hline $1983-84$ & 3.28 & 3.94 & 4.22 & 4.15 & 30.79 & 35.67 & 36.50 & 37.28 & 21.66 & 1.52 & 1.78 & 1.52 \\
\hline $\begin{array}{l}\text { Increase in last } \\
5 \text { years }\end{array}$ & 0.89 & 1.21 & 1.41 & 1.31 & 11.75 & 14.75 & 15.62 & 13.09 & 0.71 & 0.55 & 0.63 & 0.59 \\
\hline $\begin{array}{l}\text { (\%) Variation } \\
1979-84\end{array}$ & 41.00 & 44.3 & 50.1 & 16.7 & 61.7 & 70.5 & 74.8 & 54.1 & 74.7 & 56.7 & 54.7 & 63.4 \\
\hline
\end{tabular}

Source: Compiled from Pakistan statistical yearbook 1985 (Federal Bureau of Statistics, Statistics Division, Government of Pakistan

Abbreviations: (1) Kc is for Karachi, (2) Lhr is for Lahore, (3) R.P is for Rawalpindi and (4) Pwr is for Peshawar.

By juxtaposing the percentage figure for 1974-1979 with those obtained for 1979-1984 some astonishing results have been obtained which are evident from the analysis in the given below: 
Table-8: Comparison of change in price between period 1974-79 and 1979-84

\begin{tabular}{|l|l|c|c|c|}
\hline S.No. & City & $1975-79$ & $1979-84$ & Net change between the two periods \\
\hline 1 & Karachi & 36 & 54 & 18 \\
\hline 2 & Lahore & 39 & 50 & 11 \\
\hline 3 & Rawalpindi & 39 & 53 & 7 \\
\hline 4 & Peshawar & 62 & 52 & 10 \\
\hline
\end{tabular}

Source: Deduced from above Table-7(a) \& 7(b).

As seen in the above table, whereas prices of the listed six commodities in all the cities have registered a considerable further increase in the period 1979-84 over the period 1974-79, the prices have clearly increased less in Peshawar during 1979-84 period than during 1974-79 period. The researcher thus concludes that due to the aid to the refugee the prices of some of the items were not only checked but lowered as compared to the other major cities of Pakistan which were not exposed to the influx of refugees.

\section{A. People}

All the enquiries from the people about the variation in prices were somewhat oblique. Majority were of the view that all ills including prices hike were due to the refugees. The more educated ones felt that prices have remained stable during this time. They felt that some items are now available at lower prices. This source i.e., people were not very convincing as the apprehension of people regarding the refugees resulted in biased opinion and wrong answers. This source was not, any further, explored.

\section{B. Media}

The media is prompt in announcing the variation in prices of essential items especially food. A survey of national dailies revealed that during this period no untoward uproar regarding any price hike was reported. More than price hike is the unavailability of essential items of food. This country has witnessed shortages in the past. Being deficit in certain items of food shortage have often occurred in the past. Sugar and edible oil are two items of prominence. During the rationing of wheat and sugar both these items appeared in the informal markets with a dual price system. During the presence of refugees' shortages and informal markets did not exist as far as food is concerned. At least media has not reported it. No shortage of essential items was reported during this period. In Peshawar particularly consumer items given as aid to refugees are visible in the show rooms and shops. Of these edible oil and milk were openly displayed. During the refugee's arrival and the initial days of Soviet-Afghan war aid were given and distributed to refugees by humanitarian agencies. But now it has important to note that there is no such aid to refugees in Pakistan after the disintegration of USSR and end of Cold war.

During this period, also, Pakistan witnessed some good harvests making it self-sufficient in its basic staple, wheat. This had a very sobering effect on the market of other food items. In the past and today now when there is reconstruction process going in Afghanistan, it has been reported by the media that some of the essential food items like wheat, sugar and livestock is illegally exported to Afghanistan. The war and disturbances in Afghanistan also blocked those mule routs through which this trade was taking place in the past which lifted these items for local consumption bringing positive effects on prices but today these routes are once again open and many items are smuggled from Pakistan to Afghanistan and some are brought back 
War, refugees and regional implications: The impact of Afghan refugees on local society of ...

from Afghanistan to Pakistan and so these smuggled items across borders have brought negative effects on the prices of daily items of local consumption. During the period of 198590 a large number of Russian goods made appearance in the informal markets and the local population had spent these items. Cheap Russian cloth and electronics made way into local markets making them popular and the general impression is that this is a dumping device to destabilise the local market. The media fully reported on the prices and availability of such contraband items. Such situations were also there during U.S war against terrorism and attack on Afghanistan. The existence of tribal areas, however facilitated the trade in these goods. The media fully reported on the prices and availability of such contraband items. The Govt. Policy in this regard remained somewhat unexplained.

\section{Rents and real estate}

When refugees started coming in the beginning the Govt. was not prepared to settle them on their arrival immediately. The refugees, therefore, found their own haven and were spread all over the over the places. Gradually Govt. organised their settlements and various camps were established all over the province (N.W.F.P). Some for various reasons, mixed up with the local population in cities and villages. The more affluent and those who could bring some resources with them found their own lodgings. So along with the tent villages created by the Govt. a large number of refugees became a part of our towns and villages. This brought a considerable impact on rents and real estate prices in cities and villages. The price of real estate and rents went up after the influx of refugee.

In N.W.F.P particularly in Peshawar where all the head offices of the foreign humanitarian agencies and missions and administration of Afghan refugees reside has had a real upsurge in prices of real estates and rents of the houses and shops. In the survey of trade and commerce rents of the shops were tried to explore but with limited success. Neither the refugees nor the local population would reveal the correct rate of rents. Data was collected for all shops, which were counted, but the researcher did not venture into any further analysis because it was very obvious that more than $60 \%$ of the responses on rent were incorrect. Similarly, was the situation for the residences. However, through the talk with the property dealers, it was revealed that the property dealers had a good business by lettings out houses etc. According to the researcher inquiry from local people and other official documents, a house worth Rs. 5,000/- per month in 1980 was worth then about 15,000/- in 1985, with a condition of two years of advance rent. Many property dealers confirm this. For the refugees the rent per capita was not high, as multiple families would reside in one house. These was true for a large number of refugees residing around Peshawar. The local residents who moved into Peshawar for business or services faced tremendous difficulty in obtaining houses at affordable rents. There is no doubt that this category of Pakistani population suffered a lot. Today there are houses in Peshawar in Model towns like Hayatabad and University town, where the refugees give the rent of a house ranging from about 10,000 to 50,000 rupees per month.

The local owners of the house especially in University Town area where majority of well-off refugees and foreign missions or agencies are residing move out to less expensive areas renting out their own houses to these agencies on high rents. The Cantonment area did not witness this kind of situation. The refugee and foreign missions and agencies were and are discouraged to occupy hoses in the cantonment for security reasons. The city areas and nearby villages, form where the refugees could communicate daily to the urban centres for job and business, faced a 
major housing problem. Peshawar fetched the same rents as Karachi and Islamabad, another two high rent cities though for different reasons. The situation in villages was, however, different. Village did not have the tradition to let out houses. In N.W.F.P a house was given to a tenant or any other body else free of rent in return for certain free services to the landlord. There was no renting of houses in village of N.W.F.P. Majority of the refugees however not residing in the camps and could not afford high rent in the cities took over residences in the villages where rents were comparatively low. It can be said that one sector which has registered increase in prices is the real estate. Since the supply cannot be adjusted in the short run to the demand, the prices increase. Many refugees have bought houses or built houses on bought lands. The Govt. regulations does not permit the refugees to own property, but it was revealed through different sources that the refugee own property now. It is said that the revenue staffs themselves have showed the refugees the ways and means to bypass the Govt. regulations. Where it is true or false the fact is that large number of refugees own property in N.W.F.P through by bribing the officers or by getting the Pakistani N.I.C (National Identity Card).

\section{Social impacts}

The social impacts include social integration and social diffusion of both societies (intermarriages, customs and traditions), burden on health and education facilities, increase in criminal acts, drugs peddling and etc. which have been discussed below in detail.

\section{A. Social integration}

Before going deep into analysis of social impacts, first some question were asked about local people attitude towards arrival of Afghan refugees and present perception of the local people after hosting refugees for about quarter of century. So, from the study it reveals that they were received well during arrival because of Muslim brotherhood and were given land to pitch their tents, water to drink, food to eat and clothes to wear. One of the objectives of the researcher was to find out whether initial feelings and spirit of Muslim brother hood and sympathy has resulted in a concrete shape by way of social integration among the refugees and the host population. So, the indicator of social integration would be the intermarriages ratio between the local and the refugees. So, the ratio from the four different locations shows that $76 \%$ of local people and $34 \%$ of refugees out of total sample said that there are no intermarriages taking place between the both communities even having same culture, language, religion and ethnicity. Although a small proportion of about $34 \%$ of refugees and $20 \%$ of local said that intermarriages are taking place in a small scale in both communities. About the low trend of intermarriages, it was dig out by the researcher from both the communities that intermarriages are not taking place on large scale because of difference in culture and customs and traditions. Refugees demand for pride price and because of temporary stay of refugees in Pakistan and also the local and refugees don't like exogamy.

\section{B. Health}

In initial days the influx of refugees created lot of sanitation and hygienic problem. It is obvious that overpopulation causes large number of problems. Refugees live unhygienic life. They were actually the residents of the hilly areas, where the people living in far and wide hilly stations with out any populated location. In Peshawar due to the influx of refugees the population doubled. Refugees are also living dirty and unhygienic life, which resulted in sanitation 
War, refugees and regional implications: The impact of Afghan refugees on local society of ...

problems. The unhygienic conditions also resulted in spread of some communicable diseases in Peshawar like Dysentery, diarrhoea, Lashminia, Gynaecological disorders, worm infections, Malaria and T.B etc. Some of these diseases were brought by refugees or graved by the refugee's influx, which resulted the spread of these diseases into local society. Donor agencies and Govt. of Pakistan have established BHU (Basic Health Units) in camps for the treatment of refugees. But the Refugee's influx is not controlled by these facilities and they have created lot of burden and overcrowd ness in local hospitals.

\section{Education}

Although there are schools for refugee's children in camps but still the refugee's influx have overcrowded the local schools. When the people were asked about the satisfaction about the local education and facility in the local govt. schools for their children. About $77 \%$ people expressed their dissatisfaction about the facilities and education standard for their children in local schools due to influx of refugee's children enrolment in these schools. Beside it, there are a lot refugees children studying in the local Madras's with the local children. There are Afghan teachers in these Madras's, which have diverted the attention of the local people and both refugee's children from syllabus to Afghan Jihad and Terrorism and Anti-American and Antiwestern perception.

\section{Crimes (Kalashinkov culture)}

When in an area a large number of outsiders are living or come to live, they create security problems and disturb the peace of the locality. When questions were asked from the local people about the peace and security issue in the locality and responsibility for it. About $60 \%$ local people said that with the influx of refugees there is an increase in the crime ratio. Day to day dacoity, Murder etc are now common in the locality. About 53\% of Afghan refugees denied their responsibility and said that local people commit crimes and blame refugees for it. About $33 \%$ refugees said that there are some refugees who have destroyed the image of all refugees by involving in various types of crimes. Beside this, it is evident that before Afghan war, there was no automatic weapon with civil people in N.W.F.P. Now one can see everywhere Kalashinkov in N.W.F.P. according to an estimate there are about 3.5 million Kalashinkov in Pakistan with the local people. So, refugees are responsible for the spread of these weapons to the local society.

\section{E. Drugs peddling (drug culture)}

Questions about the drugs culture and drugs peddling in Pakistan. About $79 \%$ local people responded that the influx of refugees caused and refugee are responsible for the spread of heroin and other such drugs in Pakistani society. It is clear from the history of Pakistan that before 1980's there was no drugs culture and drug addicts in Pakistan. Hashish was used in Medicines before the refugee's arrival in Pakistan. Today the number of drug addicts in every city of Pakistan is unbelievable. The drug culture was brought by the superpower rivalries in Pakistan, in which the Afghan war fighters were allowed to cultivate poppy and then making of heroine in the factories established with the help of western powers of these poppies to support Afghan war fighters financially. So with this the drugs business enlarged in Pakistan and resulted in drugs addiction of its own people. Today drug addiction is not only confine to common people but it is common in school, colleges and universities of Pakistan. 


\section{Conclusion}

To summarize and conclude while undertaking this study the primary objective of the researcher was to throw light on the apprehensions of the people of N.W.F.P regarding the refugees. It was generally believed that the refugees are and will be a burden on the National economy. Refugees created unemployment, unprecedented problems which the local administration is not able to cope with. Prices increased, shortages of food and other essential items occurred due to Refugees and local economy is disrupted. The refugees will taking over jobs from the local labour and put local business into tough competition. The people's perception also included relations of the refugees with the local population to go tense creating social chaos in the society. About social impact of Afghan refugees on the local society of N.W.F.P only some selected issues i.e., social integration, Education, Health, Crimes and drugs peddling were studied to dig out the social impact of refugees on the local population.

First social integration was studied. It was considered important to ask about the intermarriages between the local and refugees' population. About intermarriages, $12 \%$ locals and 30\% refugees said yes, that marriages are taking place between local and refugees. Beside it majority of people consider that intermarriages don't taking place because of the differences in the custom and traditions and refugees temporary stay in Pakistan. Statistics from directorate of health shows it that communicable diseases spread due to influx of refugees. These were mainly four diseases (a) dysentery, (b) diarrhoea, (c). Worm infections, (d). Gynaecological disorder. Beside government of Pakistan and donor agencies have established BHU (Basic Health Units) were established for refugee in which on average one doctor is available for about 500 to 700 people. But still there is a lot of burden on local hospitals due to the influx of refugees.

About education, the refugees were provide schools in Camps to educate their children, but they are not only confine to those camp's schools, and there a lot number of refugee's children in local school and also in local Madras's where they have turned the attention of local young people towards Afghan Jihad and Terrorists activities. About refugees there is a Popular belief that the influx of refugees has increased the population of the locality, which resulted in the increase in crime rate. They are also involved in day-to-day Dacoity, Murder cases and all other such type of criminal acts. Prior to Afghan war, there were no drug culture and drug addicts. Majority of the people considered refugees responsible for the drugs culture and drugs peddling in N.W.F.P during interview. On economic side three sectors were investigated i.e., the employment and wages of the local population, the impact on the prices of essential goods and the involvement of the refugee population in trade and commerce of the local economy.

The impact of prices show that whereas prices of essential items did change but this change was to the lesser extent in N.W.F.P during the stay of refugees here than in the past. Also evident in this investigation was a fact that Peshawar registered the lowest increase in the prices of basic commodities of consumption compared to Karachi, Lahore and Rawalpindi the other major cities of the country. Never during the stay of refugee here, there has been uproar of any kind of shortage and unprecedented price hike of any single essential commodity between 1980 and 1987. No newspaper reported such phenomena. The local population also benefited from the food aid, which entered into local markets from the donor network.

The existing informal markets in contraband good further flourished and to this were added Russian made goods making the local population take chance on buying cheap refrigerators, 
War, refugees and regional implications: The impact of Afghan refugees on local society of ...

air conditioners and electronics at half the prices of comparable to Japanese and western goods. The stabilisation of prices and putting a check on inflationary trend was possible because of the refugee phenomena. The upsurge in the real estate and rents did occur because in short run the supply could not be adjusted to demand. The moneyed section of the society was able to add to their assists due to the refugee's presence. The hypothesis that prices would stabilize was thus established. The hypothesis that refugees would enter the local unskilled labour market, reduce the wage level had found to be true.

The study of the sample areas reveals that the major impact on the local labour has been in the unskilled class. The wages not increased as compared to other items of daily use. The standard of living of labour class in basic items like food and clothing went down. Only those people benefited of cheap labour were the people who were involved in construction industry, agriculture land, and property owners and industries. The intercity wage rate shows that Peshawar had lowest wage rate amongst the 12 major cities in Pakistan. The third hypothesis, which was that refugee's population, would enter into the mainstream of the economy and will be involved in trade and commerce was also established. As evident from the survey refugee's traders have taken a sizeable portion of local trade in Peshawar.

Study undertaken shows that refugees have made huge investment in the prime areas and business of the local economy. Refugees has not occupied a sizeable portion in new markets constructed in Peshawar after their arrival but has also occupied smart share in old market. The other part of trade and commerce was the vendor, which was surprising that refugees have surpassed the local population in this sector. This big amount of investment in local economy and better standard of life is today a big hurdle in the way of repatriating refugees back to Afghanistan because the Afghan refugees do not want now to let their well-established business in Pakistan and to return back.

\section{Recommendations}

Based on the findings and analysis of the governance approaches in an ungoverned territory, it is derived that state building is the only solution for integrating an ungoverned territory in mainstream governance of the state. The existing literature on state building and resilience is only focusing on developing tangible dimensions of state governance thus focussing only on developing capacity of formal state institutions. This paper presents recommendations on the basis of the multidimensional perspective thus focussing on developing both tangible and intangible dimensions of state governance and state-society relations. For a better integration of the tribal society (FATA) in the mainstream governance of Pakistan, the following recommendations are suggested:

- The key suggestion is that the Pakistani state should take serious steps to develop the tribal area instead of using the coercive methods when dealing with the tribal society.

- Provision of public goods and basic social services, including security, justice, education, health and other such facilities should be on the top agenda of the government of Pakistan.

- Trust building between Pakistani state and the tribal society is the most important intangible dimension for the extension of state authority in the tribal areas of FATA.

- Local ownership of all developmental works and indigenous support from the tribal people in this regard is very important. 
- Devolution of power to the local authorities by aligning formal and informal authorities is also needed. This will help the government formal authority to work more effectively and develop itself with the passage of time.

- There should be a new social contract between tribal people and Pakistani state especially with regard to monopoly on the use of force and taxation. By mutual trust the state and the tribal society can develop these two avenues.

- Tribal people at grassroots should be represented in reforms processes regarding FATA.

- For its legitimacy, the state should address all triggers of conflict between the state and the tribal society. These are poverty, exclusion of tribal society, and lack of representation in national politics, marginalization and the underdevelopment of tribal areas. The state should include the tribal areas in all its development processes at national level.

- The delivery of justice and the Pakistani court system to the tribal people should also be ensured by the Pakistani state.

\section{References}

Afghan Commissionerate, Hayatabad, Peshawar (N.W.F.P), Report by Ghulam Nabi Additional Commissioner Logistics, P. 12-18.

Ahmad, S. (1994, November 5). Rs. 100 b worth smuggling Subverts the Economy. Dawn Beatty, J., \& Gwynne. S. C. (1993). The outlaw law bank. Random House.

Boesen, I. W. (1990). Honour in exile: Continuity and change among Afghan refugees. In E. W. Anderson \& N. H. Dupree (Eds.), The cultural basis of Afghan nationalism. (pp. 160-174). Pinter.

Commissionerate of Afghan Refugees. (1980). Afghan refugees in Pakistan.

Dawn (1998 January 1); and also see Zahid Hussain, 'Pakistan hostage to the Mullahs', Newsline (Karachi), May 1992, pp 28-32.

Dawn, (1998, September 2).

Directorate of Health, Peshawar (N.W.F.P) Report on Health Situations in N.W.F.P in the "Daily Mashriq", p. 2.

Effendi, Y. (1991). The Soviet-Afghan military perspective - The waning Afghan Jihad and its effects on the Pakistan's North West Frontier Province (N.W.F.P), Biannual Research journal (28). Area Study Centre, University of Peshawar, Pakistan.

Farr, G. M. (1990). Afghan refugees in Pakistan: Definitions, repatriation and ethnicity. In Anderson and Dupree (Eds), The cultural basis of Afghan Nationalism (pp. 134-143). Pinter Publishers

Haq, I. (1996). Pak-Afghan drug trade in historical perspective. Asian Survey, 36(10), 945-963. https://doi.org/10.2307/2645627

Herald, (1992, September 19), pp 23-28.

Hussain, F. (1982). The possible ecological impact of Afghan refugees on the natural vegetation of N.W.F.P, Pakistan. Six Monthly Journal of Research, 11(winter). 3747.

Levitsky, M. (1989). US Assistant Sectary of State for International Narcotics, on Drug Trafficking to House Committee (Washington, DC: Government Printing Office, 8 January 1989), pp 235-456.

Rizvi, H. A. (1984). Afghan refugees in Pakistan: Influx, humanitarian assistance and implications. Pakistan Horizon, 37(1), 40-61. https://www.jstor.org/stable/41403907 
War, refugees and regional implications: The impact of Afghan refugees on local society of ...

Refugee Council in association with the British Agencies Afghan groups. (May 1991). "Silent Voices \# 1", May 1991, p. 14.

Samadani, Z. (1982). 'The Afghan refugees in Pakistan: the human aspect', Pakistan and Gulf Economist, 9-Samadani, Zafar. 1994. 'Pakistan's forest resources: hazards of depletion', Dawn, 11-17 June 1994.

Shahid, S. (1994, March 19). Cross border illegal Trade on Pak-Afghan border. The News.

Statistical Survey (2000-2001). Govt. of Pakistan Survey.

Statistical Survey (2003). Govt. of Pakistan Survey.

The Daily Mashriq (2000, December 2). Afghan Refugees and Social Evils in Local Society of N.W.F.P.

The Economist, (1987, December 20), London. Cross border smuggling on Pak-Afghan border. The New York Times. (1987, September 21). Pakistan Govt. Advertisement.

The Pakistan Times, 6 April 1995; Pakistan Narcotics Control Board, Survey on Drug Abuse in Pakistan (Islamabad: Narcotics Control Board, 1988-89), pp 7-86; and Ikramul Haq, Pakistan From Hashish to Heroin (Lahore: Annoor Printers \& Publishers, 1991).

Kartha, T. (1997). The diffusion of light weapons in Pakistan. Small Wars \& Insurgencies, 8(1), 71-87. https://doi.org/10.1080/09592319708423163

The Daily Mashriq. (1992). Dost, Muhammad. Lashminia in Afghan Refugees' Camps.

Weinbaum, M. G. (1993). The Impact and legacy of Afghan refugees in Pakistan. In J. Henery Korsen (Eds.), Contemporary problems of Pakistan. Westview Press, 1993.

Yousafzai, R. (1991, November 11). The Economic Burden of Afghan Refugees. Frontier Post.

\section{Notes:}

\footnotetext{
1 Thus, the sources, which were tapped for information on prices were: i). Government Documents such as Publication of Statistics Division, Govt. of Pakistan, ii). People (through survey and interviews), and iii). Media.
} 